\title{
Distribution of glyphosate and cloransulam-methyl resistant giant ragweed (Ambrosia trifida L.) populations in southern Ontario
}

\author{
Joanna Follings ${ }^{1}$, Nader Soltani ${ }^{1^{*}}$, Darren E. Robinson ${ }^{1}$, François J. Tardif ${ }^{2}$, \\ Mark B. Lawton ${ }^{3}$, Peter H. Sikkema ${ }^{1}$ \\ ${ }^{1}$ University of Guelph Ridgetown Campus, Ridgetown, Canada; \\ *Corresponding Author: soltanin@,uoguelph.ca \\ ${ }^{2}$ University of Guelph, Guelph, Canada \\ ${ }^{3}$ Monsanto Canada, Guelph, Canada \\ Received 2 August 2013; revised 2 September 2013; accepted 2 October 2013 \\ Copyright (C) 2013 Joanna Follings et al. This is an open access article distributed under the Creative Commons Attribution License, \\ which permits unrestricted use, distribution, and reproduction in any medium, provided the original work is properly cited.
}

\section{ABSTRACT}

Giant ragweed is a very competitive weed in row crop production and has been found to drastically reduce soybean yield. In 2008, giant ragweed was the first weed species with confirmed resistance to glyphosate in Canada. As of 2010 there were 48 locations with confirmed glyphosate resistant giant ragweed in Essex, Kent and Lambton counties. In addition, there was suspected resistance to cloransulam-methyl. The objectives of this research were 1) to conduct an expanded field survey on the distribution of glyphosate resistant giant ragweed in Ontario, 2) to determine the distribution of cloransulam-methyl resistant giant ragweed in Ontario, and 3) to determine the distribution of multiple resistant (glyphosate and cloransulam-methyl) giant ragweed in Ontario. In 2011 and 2012 giant ragweed seed was collected from 85 field sites in Essex (16), Kent (34), Lambton (23), Elgin (3), Middlesex (6), Lennox \& Addington (1), Huron (1) and Brant (1) counties. In total there are 34 additional locations confirmed with glyphosate resistant giant ragweed in Ontario. There are 11 locations confirmed with cloransulam-methyl resistant giant ragweed and 5 locations with multiple resistance to both glyphosate and cloransulam-methyl. Glyphosate resistant giant ragweed has been found in $\mathbf{4}$ additional counties.

Keywords: Giant Ragweed; Glyphosate; No-Tillage; Resistance; Soybean; Survey

\section{INTRODUCTION}

Giant ragweed (Ambrosia trifida L.) is an erect annual broadleaf weed [1]. It has a long emergence period lasting from early March to late July [2,3]. Giant ragweed also has the ability to grow rapidly and can reach heights of up to $6 \mathrm{~m}$ [4]. Historically, this species was found in orchards and non-cropped areas such as ditches and river banks in southern areas of Canada and the Midwestern and Eastern United States; however, it has recently adapted to current corn and soybean cropping systems $[1,5,6]$. Giant ragweed is a very competitive weed in row crop production. In soybean, losses of up to $92 \%$ have been reported [7]. In southwestern Ontario, the most effective herbicide for the control of giant ragweed is glyphosate [8].

However, in 2008 a location in southwestern Ontario was confirmed to have glyphosate resistant giant ragweed [9]. As a result, a survey was conducted on the occurrence and distribution of glyphosate resistant giant ragweed [10]. In 2009 and 2010 glyphosate resistant giant ragweed was confirmed at 18 and 29 additional locations, respectively [10]. All locations in 2008 and 2009 were located in Essex County in the most southwestern portion of Ontario; however, in 2010 glyphosate resistant giant ragweed was found for the first time in Kent and Lambton counties [10]. Research is required to determine if glyphosate resistant giant ragweed has spread further north and east into other counties where giant ragweed is a problem in glyphosate cropping systems. Therefore, the first objective of this study was to conduct an expanded field survey on the distribution of glyphosate resistant giant ragweed in Ontario.

In addition to glyphosate, cloransulam-methyl is re- 
commended for the control of giant ragweed in soybean in Ontario (OMAFRA, 2011). Cloransulam-methyl (17.5 g a.i.h $\left.{ }^{-1}\right)+\operatorname{Agral} 90$ (0.25\% v/v) + UAN 28\% (2.5\% v/v) applied post emergence provided $93 \%$ to $96 \%$ control of glyphosate resistant giant ragweed 8 weeks after application (WAA) [11]. However, resistance to cloransulammethyl in some glyphosate resistant giant ragweed populations is suspected [11]. Research is required to determine if populations of giant ragweed in Ontario are resistant to cloransulam-methyl and furthermore if there is multiple resistance to both glyphosate and cloransulam-methyl. Thus, the second objective of this study was to determine if there is cloransulam resistant giant ragweed in the province and furthermore if there is multiple-resistant giant ragweed.

\section{MATERIALS AND METHODS}

\subsection{Seed Collection}

In 2011 and 2012 giant ragweed seed was collected from 85 field sites in Essex (16), Kent (34), Lambton (23), Elgin (3), Middlesex (6), Lennox \& Addington (1), Huron (1) and Brant (1) counties in Ontario. Survey methods were consistent with a previous survey conducted on the occurrence and distribution of glyphosate resistant giant ragweed in Ontario [10]. Field sites were located by farmers and agriculture retailers contacting us regarding suspicious fields with poor control of giant ragweed with glyphosate or by driving down country roads and observing giant ragweed plants in fields from the road.

Beckie et al. [12] reported heavy infestations of a single weed species surviving herbicide treatment is the best indication of resistance so seed was collected from 82 soybean and 3 corn fields where giant ragweed was often the only weed present. Giant ragweed plants in these fields were found at the field entrance, along the edges of the field, in dense patches located randomly in the field, scattered throughout the field, or sparse throughout the field. Seeds were collected when they reached maturity (brown in colour) in the fall from September to October.

When seed was collected, the date, road name, nearest intersection, grower name/field name, approximate field acreage, approximate percent of field infested, other weed species present and distribution pattern throughout field was recorded. In addition, GPS coordinates were taken at each site.

To remain consistent with the previous survey [10], seed was collected from at least 20 plants per site. Approximately the same amount of seed was collected from each plant. Seed heads were clipped off the plants just below the flower heads, stored in paper bags, and dried under room conditions of $23^{\circ} \mathrm{C}$ for approximately two weeks. Seed was manually removed from the seed heads, cleaned of any debris then temporarily stored in labelled zipper storage bags.

\subsection{Glyphosate Resistance Testing}

Seed dormancy was broken using methods consistent with Stachler [13] and Vink et al. [10]. Potting soil (PRO-MIX PGX, Premier Tech Horticulture, Rivière-duLoup, QC, Canada) was used to fill 18 cell greenhouse transplant trays half full. Fifty seeds from each population were placed in a single cell and covered with additional potting soil. Each cell was labeled with the population name and date of seeding. The cells were watered and placed in a refrigerator for at least 10 weeks at a temperature between $3^{\circ} \mathrm{C}$ and $5^{\circ} \mathrm{C}$. After 8 to 10 weeks, seed was checked for germination.

Once seeds had germinated, potting mix (PRO-MIX PGX) was used to fill $10 \mathrm{~cm}$ pots and individual seedlings were transplanted into each pot cell. Seedlings were watered and placed in a growth room with a photoperiod of 16 hours, a daytime temperature of $25^{\circ} \mathrm{C}$ and a nighttime temperature of $20^{\circ} \mathrm{C}$. All seedlings were watered daily with a 20-20-20 fertilizer solution.

A population collected from Kent County, Ontario was initially screened for glyphosate resistance to confirm susceptibility to glyphosate and was used as the susceptible control. Twenty plants from each population were screened for glyphosate resistance. Plants were grown to the two to four node (four to six leaf) stage and glyphosate was applied at $1800 \mathrm{~g}$ a.e. ha ${ }^{-1}$. Glyphosate was applied using a chamber sprayer with a single 8002 even flat fan nozzle (TeeJet, Wheaton, IL, USA) calibrated to deliver $210 \mathrm{~L} \cdot \mathrm{ha}^{-1}$ of water at $276 \mathrm{kPa}$.

Control ratings were taken 1 day after application (DAA) and 1, 2, and 4 WAA. In addition to visible control ratings, at 4 WAA plants were identified as dead or alive. Plants exhibiting symptoms similar to the susceptible check (necrotic growing point) were identified as being dead and plants exhibiting a healthy growing point were identified as being alive. A population was determined to be resistant if at least one plant survived the herbicide application 4 WAA [12].

\subsection{Cloransulam-Methyl Resistance Testing}

Ten plants from each population were screened for cloransulam-methyl resistance, since it is currently recommended for control of giant ragweed in non-GMO soybean [8]. The population from Kent County was initially treated with cloransulam-methyl to confirm its susceptibility and was used as the susceptible control. Plants were grown to the two to four node (four to six leaf) stage and cloransulam-methylwas applied at a rate of 17.5 g a.i. $\mathrm{ha}^{-1}+$ Agral $90(0.25 \% \mathrm{v} / \mathrm{v})+$ UAN 28\% $(2.5 \% \mathrm{v} / \mathrm{v})$. Cloransulam-methyl was applied using the same procedure as above. 
Control ratings were taken 1 DAA and 1, 2, and 4 WAA. In addition to visible control ratings, at 4 WAA plants were identified as dead or alive. Plants exhibiting symptoms similar to the susceptible check (necrotic growing point) were identified as being dead and plants exhibiting a healthy growing point were identified as being alive. If a single plant from a population had survived the herbicide application 4 WAA, a population was determined to be resistant [12].

\section{RESULTS AND DISCUSSION}

\subsection{Glyphosate Resistance}

In 2011 giant ragweed seed was collected from 50 field sites in Essex (16), Kent (19), Lambton (10), Elgin (2), Middlesex (2) and Lennox \& Addington (1) counties in Ontario. Out of the 50 populations collected, 23 were confirmed with glyphosate resistant giant ragweed (Figures 1 and 2). Resistant populations were found in Essex (10), Kent (7), Lambton (4), Middlesex (1) and Lennox \& Addington (1) counties (Figure 1). This study confirms the presence glyphosate resistant giant ragweed in two additional counties (Middlesex and Lennox \& Addington) outside of the counties surveyed by Vink et al. [10]. The percent of glyphosate resistant giant ragweed plants in 19 populations was less than $50 \%$ (Table 1). There were 2 populations with $51 \%$ to $60 \%$ and 2 populations with 81 to 90\% glyphosate resistant giant ragweed plants (Table 1).

In 2012 giant ragweed seed was collected from 35 sites in Kent (15), Lambton (13), Elgin (1), Middlesex (4), Huron (1) and Brant (1) counties in Ontario. Of the 35 sites surveyed, 11 sites were confirmed with glyphosate resistant giant ragweed (Figure 1). Glyphosate resistant giant ragweed populations were found in Kent (5), Lambton (2), Middlesex (2), Elgin (1) and Huron (1) counties (Figure 1). In 2012, two additional counties (Elgin and Huron) have been confirmed with glyphosate resistant giant ragweed in addition to the counties surveyed by Vink et al. [10] and those counties surveyed in 2011. The percent of glyphosate resistant giant ragweed plants at nine sites was less than $20 \%$ (Table 1). At two sites $31 \%$ to $40 \%$ of the giant ragweed population was resistant to glyphosate (Table 1).

Overall, there is a low level of resistance at the sites surveyed for glyphosate resistant giant ragweed in 2011 and 2012. Of the 34 sites confirmed with glyphosate resistant giant ragweed, 30 sites had less than $50 \%$ of the giant ragweed population resistant to glyphosate (Table 1). The percent of glyphosate resistant giant ragweed at 4 sites was greater than $50 \%$ (Table 1). It is suspected that growers with giant ragweed populations that have a lower level of resistance may be using herbicides with multiple modes of action as well as a diverse crop rotation. Growers with giant ragweed populations that have a higher level of resistance may have used glyphosate more frequently in the past.

\subsection{Cloransulam-Methyl}

In 2009 and 2010 giant ragweed seed was collected from 102 field sites in Essex (70), Kent (21), Lambton (10), and Waterloo (1) counties in Ontario [10]. Of the 102 populations, 1 site was confirmed with resistance to cloransulam-methyl (Table 2). This site confirmed with cloransulam-methyl resistance was also resistant to glyphosate (Table 3). This multiple resistant site was found in Essex County (Figure 3). The percent of cloransulammethyl resistant giant ragweed plants in this population was less than 50\% (Table 3).

In 2011 giant ragweed seed was collected from 50 field sites in Essex (16), Kent (19), Lambton (10), Elgin (2), Middlesex (2), Lennox \& Addington (1) counties in Ontario. Of the 50 populations collected, 8 sites were confirmed with resistance to cloransulam-methyl (Table 2). Resistant populations were found in Essex (2), Kent (3), and Lambton (3) counties (Figure 2). Three of the populations with cloransulam-methyl resistance were also resistant to glyphosate (Table 3). These multiple resistant sites were found in Essex (1), Kent (1), and Lambton (1) counties (Figure 3). The percent of cloransulam-methyl resistant giant ragweed plants at all populations in 2011 was less than $30 \%$ (Table 3).

In 2012 giant ragweed seed was collected from 35 sites in Kent (15), Lambton (13), Elgin (1), Middlesex (4), Huron (1) and Brant (1) counties in Ontario. Of the 35 sites surveyed in 2012, 2 sites were confirmed with resistance to cloransulam-methyl (Table 2). Both resistant populations were found in Kent County (Figure 2). Of the two sites confirmed with cloransulam-resistant giant ragweed, one site was also resistant to glyphosate (Figure 3). The percent of cloransulam-methyl resistant giant ragweed plants in this population was less than 10\% (Table 3). Overall, the percent of giant ragweed resistant to cloransulam-methyl across all sites from 2009 to 2012 was less than $50 \%$ (Table 2). The low level of giant ragweed resistant to cloransulam-methyl may be due to growers frequently using glyphosate for control of giant ragweed rather than cloransulam-methyl.

\section{CONCLUSION}

In summary, this survey demonstrates that glyphosate resistant giant ragweed is no longer confined to the southwestern portion of Ontario. Since the initial assessment of its distribution in Ontario [10], the presence of glyphosate-resistant giant ragweed has been confirmed in four additional counties. This is the first survey in Canada to document cloransulam-methyl resistance and multiple resistance in giant ragweed in Ontario. 


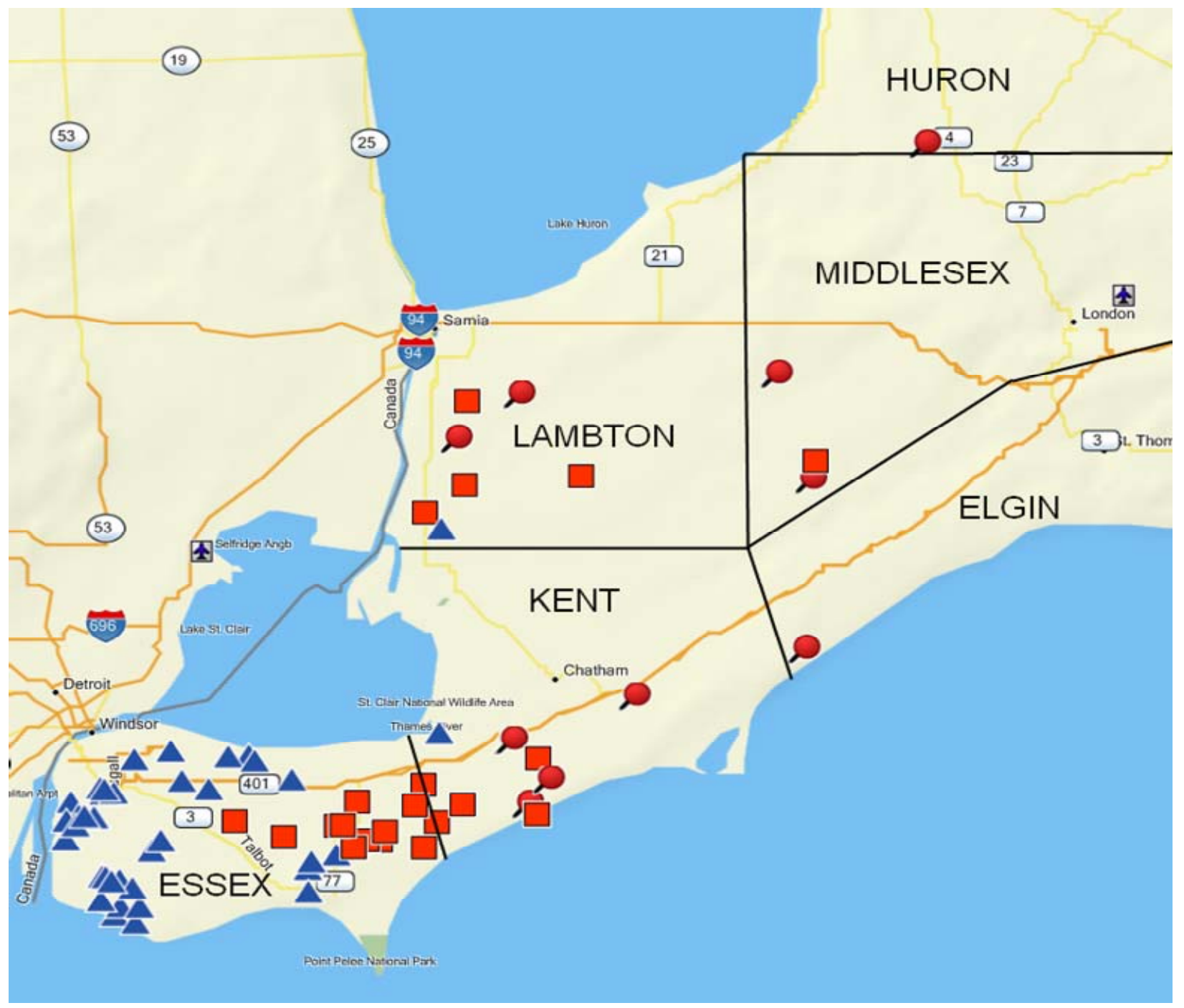

Figure 1. Distribution of glyphosate resistant giant ragweed in Ontario in 2009, 2010, 2011 and 2012. ${ }^{\mathrm{Z}} 2009$ and 2010 data taken from previous survey conducted (Vink et al., 2010b).

Table 1. Percent of giant ragweed samples resistant to glyphosate in study populations collected from soybean production fields across southwestern Ontario in 2011 and 2012.

\begin{tabular}{cccc}
\hline \multirow{2}{*}{ Percent of Sample Resistant } & & Number of Sites & \\
\cline { 2 - 4 } & 2011 & 2012 & Total \\
\hline $1-10$ & 27 & 24 & 51 \\
$11-20$ & 9 & 7 & 5 \\
$21-30$ & 3 & 2 & 3 \\
$31-40$ & 3 & 2 & 6 \\
$41-50$ & 4 & 0 & 0 \\
$51-60$ & 0 & 0 & 2 \\
$61-70$ & 2 & 0 & 0 \\
$71-80$ & 0 & 0 & 0 \\
$81-90$ & 0 & 0 & 2 \\
$91-100$ & 2 & 0 & 0 \\
All Classes & 0 & 35 & 85 \\
\hline
\end{tabular}




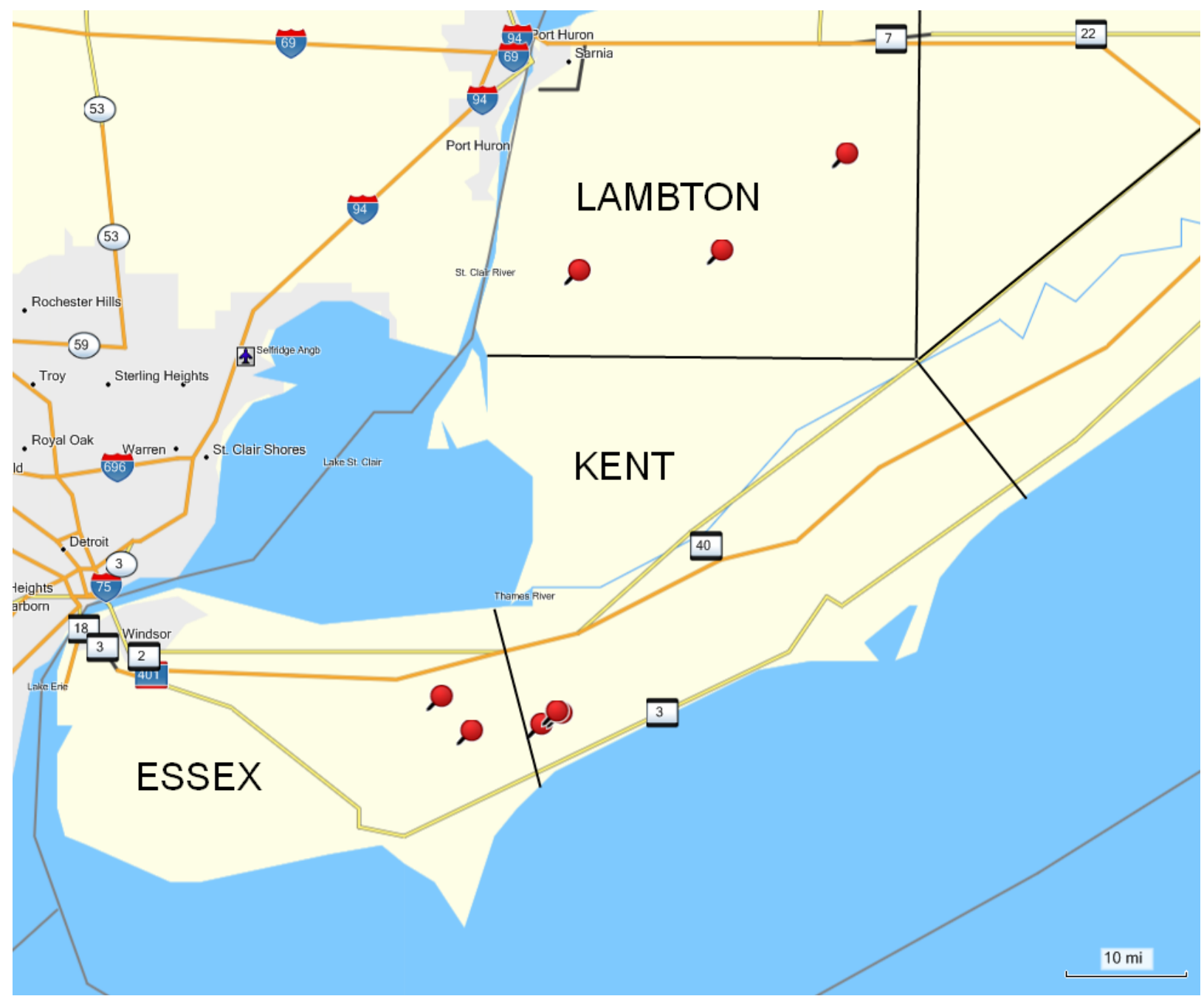

Figure 2. Distribution of cloransulam-methyl resistant giant ragweed in Ontario in 2009, 2010, 2011 and 2012.

Table 2. Percent of giant ragweed samples resistant to cloransulam-methyl in study populations across Ontario in 2009, 2010,2011 and 2012.

\begin{tabular}{|c|c|c|c|c|c|}
\hline \multirow{2}{*}{$\begin{array}{l}\text { Percent of Sample } \\
\text { Resistant }\end{array}$} & \multicolumn{5}{|c|}{ Number of Sites } \\
\hline & 2009 & 2010 & 2011 & 2012 & Total \\
\hline 0 & 53 & 48 & 42 & 33 & 176 \\
\hline $1-10$ & 0 & 0 & 5 & 2 & 7 \\
\hline $11-20$ & 0 & 0 & 2 & 0 & 2 \\
\hline $21-30$ & 0 & 0 & 1 & 0 & 1 \\
\hline $31-40$ & 0 & 0 & 0 & 0 & 0 \\
\hline $41-50$ & 0 & 1 & 0 & 0 & 1 \\
\hline $51-60$ & 0 & 0 & 0 & 0 & 0 \\
\hline $61-70$ & 0 & 0 & 0 & 0 & 0 \\
\hline $71-80$ & 0 & 0 & 0 & 0 & 0 \\
\hline $81-90$ & 0 & 0 & 0 & 0 & 0 \\
\hline $91-100$ & 0 & 0 & 0 & 0 & 0 \\
\hline All Classes & 53 & 49 & 50 & 35 & 187 \\
\hline
\end{tabular}




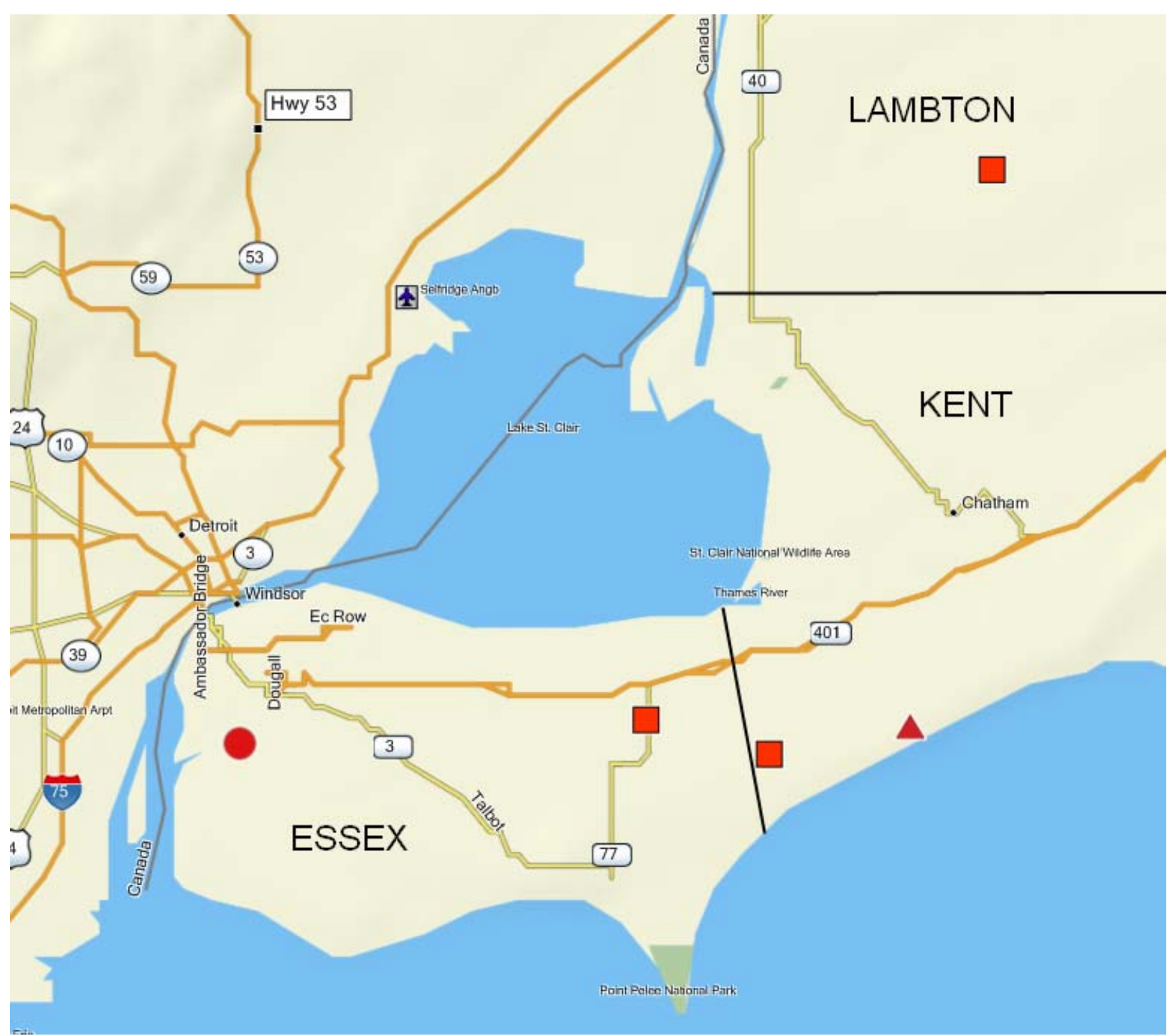

Figure 3. Distribution of multiple resistant (glyphosate and cloransulam-methyl) giant ragweed in Ontario in 2009, 2010,2011 and 2012.

Table 3. Percent of giant ragweed samples with multiple resistance to cloransulam-methyl and glyphosate in study populations across Ontario in 2009, 2010, 2011 and 2012.

\begin{tabular}{|c|c|c|c|c|c|}
\hline \multirow{2}{*}{$\begin{array}{l}\text { Percent of Sample } \\
\text { Resistant to } \\
\text { Cloransulam-Methyl }\end{array}$} & \multicolumn{5}{|c|}{ Number of Sites } \\
\hline & 2009 & 2010 & 2011 & 2012 & Total \\
\hline 0 & 53 & 48 & 47 & 34 & 182 \\
\hline $1-10$ & 0 & 0 & 2 & 1 & 3 \\
\hline $11-20$ & 0 & 0 & 0 & 0 & 0 \\
\hline $21-30$ & 0 & 0 & 1 & 0 & 1 \\
\hline $31-40$ & 0 & 0 & 0 & 0 & 0 \\
\hline $41-50$ & 0 & 1 & 0 & 0 & 1 \\
\hline $51-60$ & 0 & 0 & 0 & 0 & 0 \\
\hline $61-70$ & 0 & 0 & 0 & 0 & 0 \\
\hline $71-80$ & 0 & 0 & 0 & 0 & 0 \\
\hline $81-90$ & 0 & 0 & 0 & 0 & 0 \\
\hline $91-100$ & 0 & 0 & 0 & 0 & 0 \\
\hline All Classes & 53 & 49 & 50 & 35 & 187 \\
\hline
\end{tabular}




\section{ACKNOWLEDGEMENTS}

The authors acknowledge Chris Kramer for his expertise and technical assistance in these studies. Funding for this project was provided in part by Monsanto Canada Inc., the Grain Farmers of Ontario and the Agricultural Adaptation Council through the Canadian Agricultural Adaptation Program.

\section{REFERENCES}

[1] Bassett, I.J. and Crompton, C.W. (1982) The biology of Canadian weeds. 55. Ambrosia trifida L. Canadian Journal of Plant Science, 62, 1003-1010.

[2] Harrison, S.K., Regnier, E.E., Schmoll, J.T. and Webb, J.E. (2001) Competition and fecundity of giant ragweed in corn. Weed Science, 49, 224-229. http://dx.doi.org/10.1614/0043-1745(2001)049[0224:CA FOGR]2.0.CO;2

[3] Schutte, B.J., Regnier, E.E. and Harrison, S.K. (2004) Primary seed dormancy in Ambrosia trifida L. (giant ragweed). Proceedings of the North Central Weed Science Society, 59, 119.

[4] Abul-Fatih, H.A. and Bazzaz, F.A. (1979) The biology of Ambrosia trifida L. II. Germination, emergence, growth, and survival. New Phytologist, 83, 817-827. http://dx.doi.org/10.1111/j.1469-8137.1979.tb02313.x

[5] Abul-Fatih, H.A. and Bazzaz, F.A. (1979) The biology of Ambrosia trifida L. I. Influence of species removal on the organization of the plant community. New Phytologist, 83, 813-816. http://dx.doi.org/10.1111/j.1469-8137.1979.tb02312.x

[6] Johnson, B., Loux, M., Nordby, D., Sprague, C., Nice, G., Westhoven, A. and Stachler, J. (2007) Biology and management of giant ragweed.
http://www.ces.purdue.edu/extmedia/BP/GWC-12.pdf

[7] Baysinger, J.A. and Sims, B.D. (1991) Giant ragweed (Ambrosia trifida) interference in soybeans (Glycine max). Weed Science, 39, 358-362.

[8] OMAFRA, Ontario Ministry of Agriculture, Food, and Rural Affairs (2011) I. Guide to weed control. Publication 75. Queen's Printer for Ontario, Toronto.

[9] Heap, I. (2012) International survey of herbicide resistant weeds. http://www.weedscience.org/In.asp

[10] Vink, J.P., Soltani, N., Robinson, D.E., Tardif, F.J., Lawton, M.B. and Sikkema, P.H. (2012) Occurrence and distribution of glyphosate-resistant giant ragweed (Ambrosia trifida L.) in southwestern Ontario. Canadian Journal of Plant Science, 92, 533-539. http://dx.doi.org/10.4141/cjps2011-249

[11] Vink, J.P., Soltani, N., Robinson, D.E., Tardif, F.J., Lawton, M.B. and Sikkema, P.H. (2012) Glyphosate-resistant giant ragweed (Ambrosia trifida L.) in Ontario: Dose response and control with post emergence herbicides. American Journal of Plant Sciences, 3, 608-617. http://dx.doi.org/10.4236/ajps.2012.35074

[12] Beckie, H.J., Heap, I.M., Smeda, R.J. and Hall, L.M. (2000) Screening for herbicide resistance in weeds. Weed Technology, 14, 428-445.

http://dx.doi.org/10.1614/0890-037X(2000)014[0428:SF HRIW]2.0.CO;2

[13] Stachler, J.M. (2008) Characterization and management of glyphosate-resistant giant ragweed (Ambrosia trifida L.) and horseweed [Conyza canadensis (L.) Cronq.]. Ph.D. Dissertation, The Ohio State University, Columbus, 60107. 